
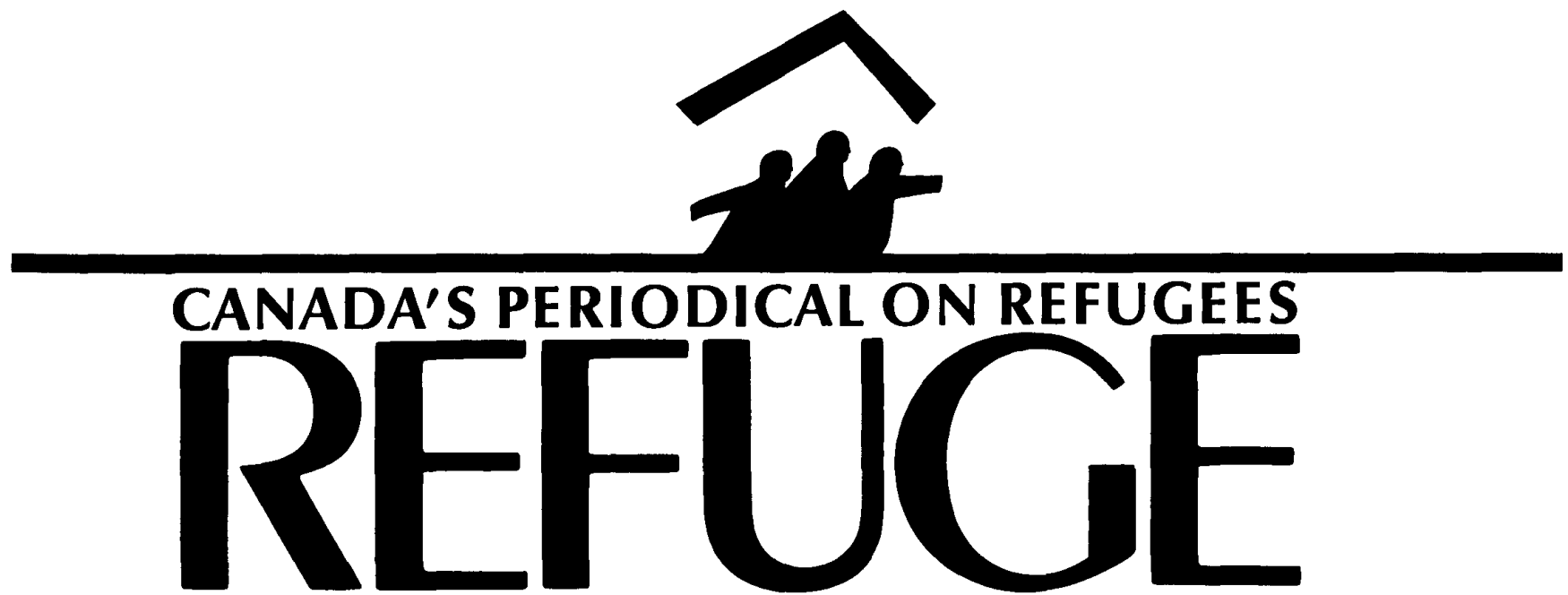

Vol. 8, No. 3

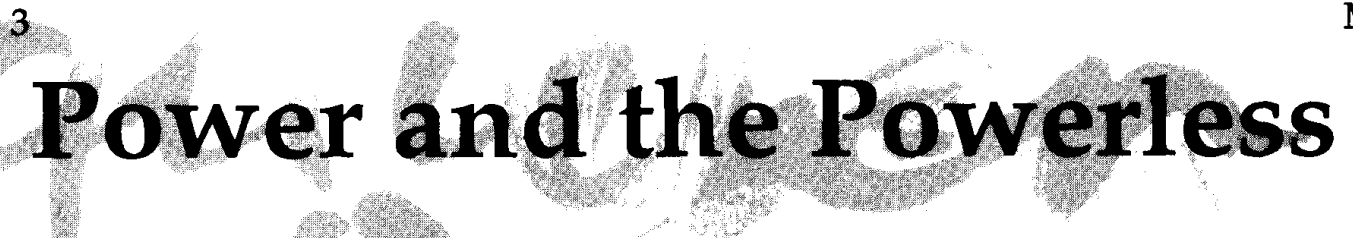

A refugee claimant from China is given a preliminary hearing under the new Canadian legislation. She is found not to have a credible claim. In desperation, she slashes her wrists. Her suicide attempt is unsuccessful. In the ensuing publicity a story emerges of her and her father's imprisonment, of a poorly pre pared duty counsel, of a hearing officer who wondered who Mr Kuomintang was Whou the yoman kept mentioning.

In Januaty in Montreal, the claim of another woman is refused. She was from Haiti. She fumped in front of a subway train. Het suicide attempt was successful. A young Vietnamese refugee in Phanat Nikhom sets himself on fire. His body is consumed by flames.

All these victims felt powerless. An three were obviously desperate. In death, they undercut the distinctions of academics and policy makers between convention and humanitarian refugees, between refugees and those displaced by civil warand repressive conditions in impovertshed nations. Self sacrifice can be the final act of an individual who, whendenied all other means to control and $g$ we some direction to his or her own life, can at least assert the right to take his or her own life.

They can also write letters appealing for us to help. We print one example of such a letter. In Canada, we can help. Ten

Continued on page 2

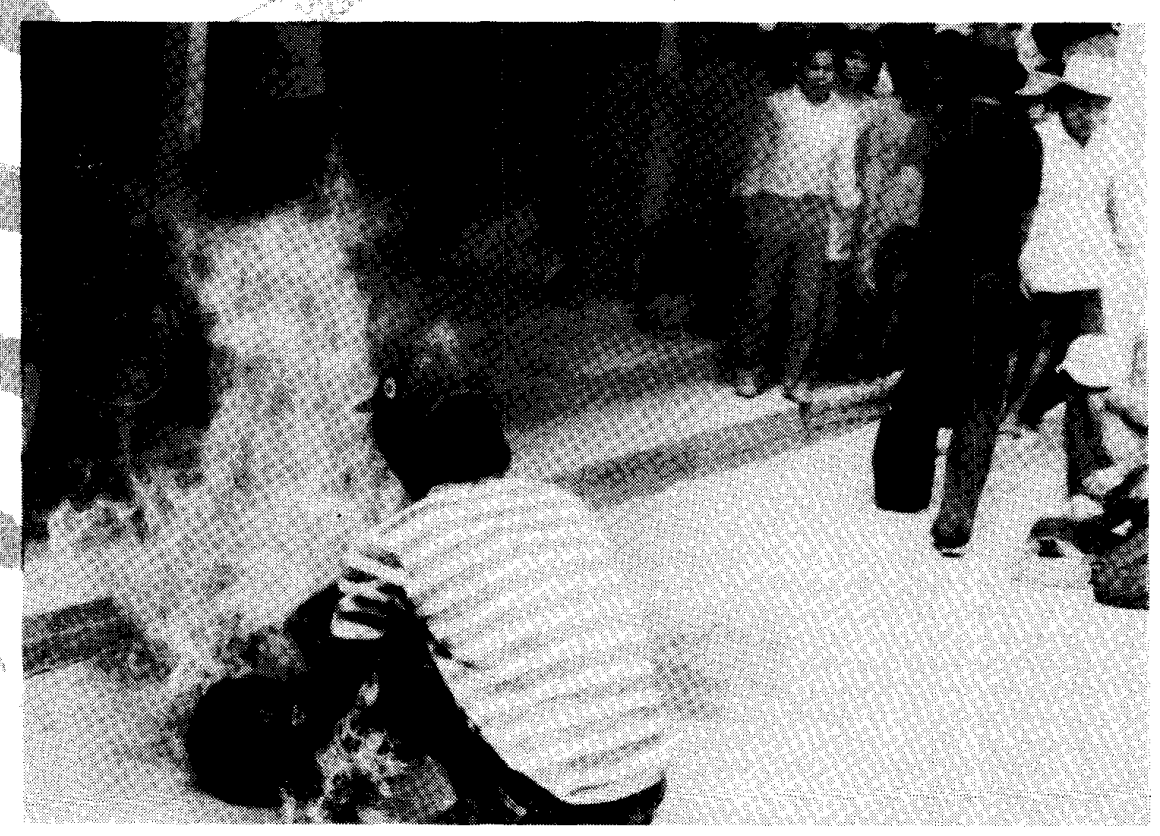

A Vietnamese refugee burns himself to death in Phanat Nikhom, Thailand.

\title{
IN THIS ISSUE:
}

Cross-cultural Co-operation among Displaced Persons by Geza Tessenyi

Uprooted by the War by Göran Rystad

"The Refugee Crisis: British and Canadian Responses"

Convictions of the Heart reoiewed by Charles Stastny

March 1989

Indochinese Refugees: Asylum and Resettlement

reviewed by Noreen Spencer-Nimmons

page 4

page 7

page 10

page 12

page 13 
years ago, Operation Lifeline was born to involve private individuals in the sponsorship of the Boat People. Legislation exists in Canada to let ordinary Canadians take the initiative in sponsoring refugees. Operation Lifeline in co-operation with the Vietnamese community has been given a rebirth in Toronto to provide a Canadian initiative in clearing up the 60,000 Vietnamese refugees remaining in camps in Southeast Asia. (In Hamilton, the chapter never died but has been active and in continuous operation for the last decade. Volunteers interested in helping to organize private sponsorships can write, care of Refuge.) Canadian citizens are not powerless.

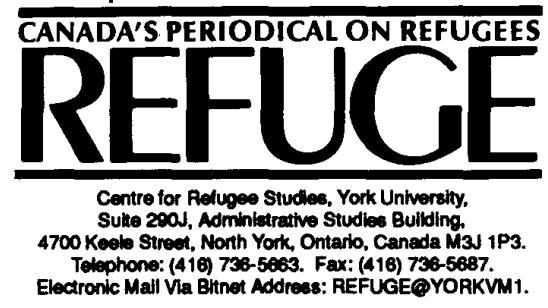

\section{Editor:}

Howard Adelman

\section{Executive Editor: \\ Alex Zisman \\ Illustrations: \\ Herminio Ordóñez \\ Circulation Manager: Helen Gross}

\section{Assistant to the Circulation Manager: Ching Man (C.M.) Wong}

Refuge is dedicated to the encouragement of assistance to refugees by providing a forum for sharing information and opinion on Canadian and international issues pertaining to refugees. It is published four times a year by the Centre for Refugee Studies. It is a non-profit, independent periodical supported by private donations and by subscriptions. It is a forum for discussion, and the views expressed do not necessarily reflect those of its funders or staff.

All materials in Refuge may be reproduced without permission unless copyrighted or otherwise indicated. Credit should be given to the author or source, if named.

Subscription rates for one year are $\$ 20.00$ in Canada and US \$25.00 overseas. Please enclose payment with your order.

Logo design:

Dreadnaught Co-operative Inc., Toron to

Layout: PAGES pivs

Second Chas Mail Regletration N $N^{2} 512$ ISSN 0229-5113
Refugees are not totally powerless either. Geza Tessenyi was a lawyer in advance of his time who pioneered in the private practice of law in contemporary communist Hungary. He fled as a refugee after receiving threats from government officials. He is now a scholar in Holland. In this issue he writes about the attempts of the broad category of displaced persons to forge a path other than self immolation. They are striving to organize.

Unlike workers who organized into unions, they do not have the power to deny their employers the fruits of their labour. Unlike the civil rights protesters of the 1960s in the United States, they do not have the right to vote, even if that right was systematically denied for almost a century. Do they have some basis for organizing on the principles of self-help and self determination? Or is Geza Tessenyi naïve? Must refugees rely on the humanitarianism and good will of their hosts to determine their destinies? Or would such reliance itself be naïve?

What did the big powers do with the millions displaced and left as flotsam in DP camps after the Second World War? As the big powers debated who should be classified as Displaced Persons and who should be classified as refugees, and therefore eligible for resettlement, Jewish refugees, among millions of others, suffered years of further indignity following the horror of the holocaust. In this issue Göran Rystad describes the historical research being undertaken in Lund, Sweden into the motives and factors that determined state policy towards refugees, displaced persons and expellees after World War II. The preliminary results do not indicate that the lives of refugees and others can be entrusted solely to the state.

In a recent conference in Oxford considering and comparing refugee policies and results in Canada and Great Britain, Canada emerged as a creative innovator in programmes for resettling refugees while, at the same time, its new programme for deterring Convention refugee

Continued on page 3

\section{Letters to the Editor}

There were a couple of inaccuracies in your article in Refuge Vol 8, No. 1 (October 1988). Is was the Tamils who arrived off the coast of Newfoundland and the Sikhs off Nova Scotia. Not the other way around.

About your comment, top p. 2 "... the Mulroney government was effusive in expressing its support for refugees and went beyond the call of duty (and, perhaps, prudence) in the speed with which ministerial permits were issued." The government had no choice: at the time there was a special pro gramme in effect for all Tamils, who were not to be deported regardless of whether they were or were not refugees because Canada was not deporting Tamils to Sri Lanka (even if they came fro West Germany!). All Tamil arrivals until the abolishing of the $B-1$ list in February, 1987 were quickly issued with Minister's Permits.

Lisa Gilad

Institute of Social and Economic Research

Memorial University of Newfoundland

I am writing to let you know about my photodocumentary work with Cambodian refugees in Bronx, N.Y. and Amherst, MA. I would like organizations that are interested in the Cambodian refugee experience and active in refugee affairs to be aware that my photographs are available for exhibitions, publications and research purposes. The photodocumentary looks at the Cambodian refugee experience in this country not just as "new faces in melting pot America" (as the mass media so often does), but as a direct consequence of historical and political events that make them distinct from other newcomers.

Through my photographs I hope to cre ate a historical and educational record of the experiences of a community of holocaust survivors from the Pol Pot regime in Cambodia and the process of rebuilding their lives in the United States.

The project has received several awards and has been exhibited in New York and Massachusetts. Please contact me if you have any ideas about how my project can be used and if you would like to see slides of prints of this documentary for possible exhibition or publication. Please also feel free to pass my name along to any groups or individuals who you think would be interested in knowing about the project.

\section{Leah Melnick}

367 N. Pleasant St.

Amherst, MA 01002

USA 
claimants within Canada came under critical examination. A brief resume of the proceedings of that conference is printed in this issue. The complete proceedings will be published in a book.

In the United States, in the face of the renewed policy of humane deterrence, some individuals have initiated a sanctuary movement for Latin American refugees in the United States. Charles Stasny reviews the book on Jim Corbett, a leader of the sanctuary movement.

Noreen Nimmons reviews another book of collected writings by Thai academics on the response of government powers, the small powers immediately affected and the policies of the First World resettlement countries. It becomes clear, that, because of the declining interest of resettlement countries, the countries of first asylum are using the Convention definition and procedures for adjudicating claims to deter new arrivals and provide a legal basis for repatriation or deportation.

There is a real dilemma. States assert their sovereignty by retaining control of who may enter a country, and, more fundamentally, who can become a member of that country. A state will not surrender such a right. When individuals throng the entry gates, such countries frequently resort to measures to halt or limit the thrust. The measures designed to protect refugees are used to limit the number of entrants.

We do not challenge the right of states to make such policies. We challenge Canadians to participate in making that policy using legal means in Canada to effect that policy, to challenge laws in the courts, and to use the law to demonstrate direct support for refugees through private sponsorship.

The distinction between humanitarian refugees, whom we select abroad under relaxed immigration criteria, and Convention refugees who claim status within Canada under a quasi-judicial procedure and a very restricted definition or a refugee, breaks down to some degree as countries of first asylum attempt to limit the arrivals of humanitarian refugees by using the convention definition; at the same time, countries of resettlement become countries of first asylum for large numbers of refugee claimants.

This means that the opportunity for private sponsorship becomes an opening for individual Canadian citizens to participate in the making of policy by legal direct action.

States have power. Refugees desper-

\section{A Letter from a Refugee Camp in Thailand}

Phanat Nikhom, February 23, 1989

Dear members of the Vietnamese Refugee Assistance Committee,

Today our camp received a new issue of Lang Van Magazine (December 1988). Fro $m$ the magazine we learned that the Committee is launching an appeal in the community to help the refugees by sponsoring them away from the refugee camps as soon as possible. I am overwhelmed with joy because you have given us hope during our most miserable life in a refugee camp. Therefore today I am writing this letter to ask you to sponsor me away fro $m$ these walls, these fences, and this barbed wire which have been imprisoning our youth and to liberate me from the threat of being repatriated to Vietnam.

I do not have any relatives living abroad, so I cannot ask them for help. You gave me a buoy to hang on for saving my life. I had been rejected by the U.S. team. I have been spending my time in this camp studying English and helping to distribute water to my fellow refugees in the camp. I tried to improve my chances of being accepted for settlement in Canada on humanitarian grounds by taking a language/skill training course, but so far I have not been lucky yet; in the meantime the situation in the camp is getting from bad to worse and the threat of repatriation is hanging heavily over our heads. Today, you, the people I did not have the honour to meet, have brought me hope. You have acted from your humanitarian heart and you make personal sacrifices to help fellow refugees like myself. I am imploring you to help me, I promise that later on, if I am allowed to settle [in Canada], I will work hard in order to repay all the expenses incurred during my sponsorship.

\section{Trinh Xuan Chinh \\ Phanat Nikhom \\ Chonburi, Thailand}

ately want some power to control their own lives. Citizens concerned with refugees already have the power to help select groups of such refugees. Will they use the power they have when they are not stirred up emotionally by day after day of television footage on the desperate plight and suffering of the refugees?

Desperate Vietnamese refugees have signed their names in blood as a symbolic statement of solidarity with those who committed suicide and as a pledge that they will resist repatriation. (A screened collage of such signatures appears on the front page.) Canadians can sign their names in ink to prevent the necessity for any such acts of desperation. As the Oxford papers recorded, the success of the Indochinese in Canada is a testament to resilience, strength and creativity when individuals are given back their dignity and offered the opportunity to make new lives for themselves.

Help restore power to these individuals by utilizing your power.

\section{News in Brief}

- Firdaus James Kharas has been appointed Assistant Deputy Chairman (Backlog) of the Immigration and Refugee Board. He will be responsble for the administration of the refugee determination system as it applies to the claimants for refugee status currently within the backlog. It is estimated that there are over 85,000 cases within the backlog. Prior to joining the Immigration adn Refugee Board, Kharas served as Immigration Policy advisor to the Minister of Employment and Immigration.

Howard Adelman, Editor

(C) Authors, 1989. This open-access work is licensed under a Creative Commons Attribution-NonCommercial 4.0 International License, which permits use, reproduction and distribution in any medium for non-commercial purposes, provided the original author(s) are credited and the original publication in Refuge: Canada's Journal on Refugees is cited. 